
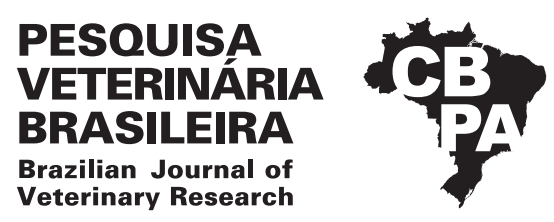

Pesq. Vet. Bras. 38(10):1918-1922, outubro 2018 DOI: $10.1590 / 1678-5150-P V B-5865$

Original Article

ISSN 0100-736X (Print)

ISSN 1678-5150 (Online)

\title{
Occurrence of hydatidosis and cysticercosis in cattle in southern Rio Grande do Sul, Brazil, from 2013 to $2016^{1}$
}

\author{
Taina S. Alberti ${ }^{2}$, Fabio R.P. Bruhn ${ }^{3}$, Valmor Lansini ${ }^{4}$, Margarida B. Raffi ${ }^{5}$, \\ Haide V. Scheid ${ }^{6}$, Rosimeri Zamboni ${ }^{6}$, Lucas Quevedo ${ }^{2}$ and Eliza S.V. Sallis ${ }^{5 *}$
}

\begin{abstract}
Alberti T.S., Bruhn F.R.P., Lansini V., Raffi M.B., Scheid H.V., Zamboni R., Quevedo L. \& Sallis E.S.V. 2018. Occurrence of hydatidosis and cysticercosis in cattle in southern Rio Grande do Sul, Brazil, from 2013 to 2016. Pesquisa Veterinária Brasileira 38(10):1918-1922. Departamento de Patologia Animal, Universidade Federal de Pelotas, Campus Universitário, Pelotas, RS 96010-900, Brazil. E-mail: esvsallis@yahoo.com.br

Hydatidosis and cysticercosis are parasitoses caused by the larval forms of the cestodes Equinococcus spp. and Taenia spp., which belong to the Taeniidae family. Their definitive hosts are canids and humans, respectively, with ruminants as the intermediate hosts and humans as an accidental host of both diseases. These parasites are responsible for large economic losses in slaughterhouses due to condemnation of carcasses and by-products. The present study reports the mean incidence rates of hydatidosis and cysticercosis in cattle slaughtered in the southern region of Rio Grande do Sul state, Brazil. The incidence rates observed between 2013 and 2016 were $19.96 \%$ and $0.9 \%$, respectively, with decreased tendency of occurrence of both diseases in those years. Despite the downward tendency of the diseases, hydatidosis presented high incidence. Hydatidosis performance over the years was characterized by significant increase in the number of cases, followed by marked decrease. Cysticercosis presented a decrease in number of cases at the beginning and the end of each year. These diseases have a significant socioeconomic impact as they are responsible for large losses in the livestock industry, due to reduced productivity and carcass condemnation, and represent a risk to public health.
\end{abstract}

INDEX TERMS: Hydatidosis, cysticercosis, incidence, cattle, Rio Grande do Sul, Brazil, parasitoses.

RESUMO.- [Ocorrência de hidatidose e cisticercose em bovinos na região sul do Rio Grande do Sul, de 2013 a 2016.] Hidatidose e cisticercose são parasitoses causadas

\footnotetext{
${ }^{1}$ Received on April 17, 2018.

Accepted for publication on April 30, 2018.

${ }^{2}$ Programa de Residência Multiprofissional e Área Profissional da Saúde em Patologia Animal, Departamento de Patologia Animal, Universidade Federal de Pelotas (UFPel), Campus Universitário, prédio 1, Capão do Leão, RS 96010-900, Brazil.

${ }^{3}$ Departamento de Veterinária Preventiva, Centro de Controle de Zoonoses, Universidade Federal de Pelotas (UFPel),, Campus Universitário, prédio 1, Capão do Leão, RS 96010-900.

${ }^{4}$ Secretaria da Agricultura Pecuária Pesca e Agronegócio, Inspetoria Veterinária, Rua Barão de Santa Tecla 469, Centro, Pelotas, RS 96010-140, Brazil.

${ }^{5}$ Departamento de Patologia Animal, Faculdade de Veterinária, Universidade Federal de Pelotas (UFPel), Campus Universitário, Capão do Leão, RS 96010 900. *Corresponding author: esvsallis@yahoo.com.br

${ }^{6}$ Curso de Pós-Graduação em Veterinária, Faculdade de Veterinária, Universidade Federal de Pelotas (UFPel), Campus Universitário, Capão do Leão, RS 96010-900.
}

pelas formas larvais dos cestódeos Equinococcus spp. e Taenia spp., pertencentes a família Taeniidae, possuem como hospedeiros definitivos canídeos e o homem respectivamente, sendo os ruminantes os hospedeiros intermediários, e o homem um hospedeiro acidental, em ambas as doenças. Estas parasitoses são responsáveis por grandes perdas econômicas em frigoríficos, devido a condenações de carcaças e subprodutos. 0 presente artigo relata que a incidência média de hidatidose e cisticercose em bovinos abatidos na região sul do Rio Grande do Sul, entre os anos de 2013 e 2016 , foi de $19,96 \%$ e $0,9 \%$ respectivamente, sendo avaliada uma tendência de queda no número de casos de ambas as doenças ao longo dos anos analisados. Apesar da tendência de queda das doenças, a hidatidose apresentou uma alta incidência. $\mathrm{O}$ comportamento da hidatidose ao longo dos anos foi caracterizado por aumentos significativos no número de casos da doença, seguidos por acentuadas quedas. Já a cisticercose apresentou uma diminuição no número de casos 
no início e no final de cada ano. Estas doenças apresentam grande impacto socioeconômico, pois são responsáveis por grandes perdas na pecuária, por redução na produtividade e condenações, além de representarem um risco à saúde pública.

TERMOS DE INDEXAÇÃO: Hidatidose, cisticercose, incidência, bovinos, Rio Grande do Sul, parasitoses.

\section{INTRODUCTION}

Cattle raising is of fundamental importance for the Brazilian agribusiness, accounting for 6\% of the Country's Gross Domestic Product (GDP) and 30\% of its agribusiness GDP. Brazil is one of the leading producers and exporters of beef worldwide. In 2015, the Country had the largest cattle herd in the world, with 209 million head, and was the second largest consumer (38.6 kg/inhabitant/year) and the second largest exporter (1.9 million tons carcass weight equivalent) of beef (Gomes et al. 2017).

Carcasses and viscera are products resulting from the slaughter of bovine animals. Cattle slaughter by-products (viscera) add value to production, because they are of lower cost to consumers compared with other beef cuts, and serve as an alternative source of protein for the lower-income population worldwide (Kale et al. 2011, Fruet et al. 2013). Several pathologies can be diagnosed during slaughter, which may result in condemnation of carcasses and by-products. The largest condemnation rate in slaughterhouses is due to parasitic lesions, such as hydatidosis, cysticercosis, and fasciolosis (Tessele et al. 2013). Parasitic infections are responsible for significant losses to the national economy because of direct and indirect losses in livestock, resulting from reduction in productivity, losses owing to sanitary condemnation and embargoes demanded by foreign consumer centers, in addition to presenting an enormous impact on health public (Mekonnen \& Kebede 2011, Rossi et al. 2014).

Hydatidosis and cysticercosis are parasitoses caused by larval forms of the cestodes Equinococcus spp. and Taenia spp. In the biological cycle of hydatidosis, the hydatid cyst constitutes the larval stage of the cestode, in which sheep, cattle, and humans are the intermediate hosts and domestic dogs or wild canids are the definitive hosts. In bovine (Cysticerccus bovis) and swine (Cysticerccus cellulosae) cysticercosis, cattle and pigs are the intermediate hosts and humans are the definitive hosts of Taenia saginata and Taenia solium, respectively (Santos 2013a, 2013b). Hydatid cysts can be observed in various organs, but the liver and the lung are the most affected, resulting in their condemnation. Cysticerci are most commonly found in the skeletal muscles, especially in those with higher blood supply, such as the heart and the masticatory muscles (Tessele et al. 2013). Lesions resulting from cysticercosis result in significant economic losses, most often leading to total condemnation of carcasses and by-products (Rossi et al. 2014).

This study aimed to report the annual incidence of hydatidosis and cysticercosis in cattle slaughtered under official inspection in the southern region of Rio Grande do Sul state from 2013 to 2016, as well as to assess the behavior of these diseases over time.

\section{MATERIALS AND METHODS}

This study conducted a retrospective analysis of the cases of hydatidosis (hydatid cyst) and cysticercosis (Cysticercus bovis) in cattle slaughtered under official inspection (Divisão de Inspeção de Produtos de Origem Animal - DIPOA) in municipalities (Arroio Grande, Canguçu, Capão do Leão, Pelotas, and São Lourenço) in southern Rio Grande do Sul from October 2013 to December 2016. Data on the incidence rates of these diseases were obtained from the database of the official inspection service of the state, located at the veterinary inspectorate of the municipality of Pelotas.

After collection, the data were classified and then submitted to descriptive and inductive statistical analyses. The time series assessed included the incidence of these diseases in cattle slaughtered in southern Rio Grande do Sul, from 2013 to 2016. To evaluate the incidence of bovine cysticercosis and hydatidosis, the monthly incidence (Formula 1) of each disease was initially calculated in each municipality. Subsequently, the following incidence rates were calculated: annual incidence in each municipality (Formula 2), mean incidence in each municipality in the period assessed (Formula 3), and the mean incidence of diseases in the region during the period assessed (Formula 4).

Time-series analyses were performed using the Gretl 1.9.12 (GNU Regression, Econometric and Time-series Library) statistical software, with analysis of existence of the tendency and seasonality components through verification of the series and their respective autocorrelation plots. Once the existence of these components was verified, the series were differentiated. After that, statistical verification was performed by means of the Augmented Dickey-Fuller test, considering a value of $p<0.05$. After observing that the data were stationary in the differentiated series, presence or absence of the tendency and seasonality components was inferred in the monthly series of cases of hydatidosis and cysticercosis from 2013 to 2016.

\section{Incidence formulas}

Formula 1. Monthly incidence in each municipality

Total number of animals that tested positive for cysticercosis /

$$
\text { Total number of animals slaughtered in the month } \times 100
$$

\section{Formula 2. Annual incidence in each municipality}

Sum of the incidence rates of each month

$\overline{\text { Total number of months with disease occurrence }}$

Formula 3. Mean incidence in each municipality in the years assessed

Sum of the incidence rates of each year

Formula 4. Mean incidence in all municipalities in the years assessed

Sum of the mean incidence rates in each municipality in the period assessed

Total number of municipalities assessed (5)

\section{RESULTS}

Mean incidence rates of hydatidosis and cysticercosis in the years evaluated (2013 to 2016) were $19.96 \%$ and $0.9 \%$, respectively. The highest and lowest mean incidence rates of hydatidosis occurred in the municipalities of Arroio Grande 
(27.72\%) and São Lourenço (6.75\%), respectively. As for cystocercosis, the highest and lowest mean incidence rates were in the municipalities of Capão do Leão (1.31\%) and Canguçu (0.58\%), respectively. Tables 1 and 2 present the incidence of hydatidosis and cysticercosis in cattle slaughtered under official inspection in southern Rio Grande do Sul, from 2013 to 2016.

Descriptive analysis of Figure 1 shows a downward trend in cases of hydatidosis in cattle from 2013 to 2016, as well as absence of seasonality. Application of the Augmented Dickey-Fuller test confirmed the presence of a downward tendency $(p<0.05)$ in the number of monthly cases of hydatidosis and the absence of seasonality. Descriptive evaluation of Figure 2 also shows a downward trend in cases of cysticercosis over the years and a possible influence of seasonality; however, after application of the Augmented Dickey-Fuller unit root test, only the presence of a downward tendency was confirmed, but seasonality was not statistically confirmed $(p<0.05)$.

Tendency-free assessment of hydatidosis presented a significant increase in the number of cases at the beginning of each year, followed by a sharp decrease. In 2015, the incidence rates were more constant, and did not present the pattern of increases followed by decreases (Fig.3). In contrast, cysticercosis presented a significant decrease in the number of cases at the beginning and the end of each year (Fig.4).

Table 1. Incidence (\%) of hydatidosis in cattle slaughtered under official inspection in southern Rio Grande do Sul, Brazil, from 2013 to 2016

\begin{tabular}{|c|c|c|c|c|c|}
\hline \multirow{2}{*}{ Region } & \multicolumn{4}{|c|}{ Incidence (\%) of hydatidosis in cattle } & \multirow{2}{*}{ Mean } \\
\hline & 2013 & 2014 & 2015 & 2016 & \\
\hline Pelotas & $18.63(3211)$ & $25.60(13716)$ & $24.79(12048)$ & $21.55(7403)$ & 22.64 \\
\hline Canguçu & $10.40(961)$ & $21.80(3697)$ & $23.43(4074)$ & $21.19(3570)$ & 19.21 \\
\hline São Lourenço & $9.83(588)$ & $7.76(1566)$ & $5.36(982)$ & $4.06(849)$ & 6.75 \\
\hline Arroio Grande & $10.69(41)$ & $32.72(949)$ & 37.70 (999) & $29.75(628)$ & 27.72 \\
\hline Capão do Leão & $29.67(89)$ & $17.50(412)$ & $24.19(542)$ & $22.48(563)$ & 23.46 \\
\hline Total & 15.84 & 21.08 & 23.09 & 19.81 & 19.96 \\
\hline
\end{tabular}

Table 2. Incidence (\%) of cysticercosis in cattle slaughtered under official inspection in southern Rio Grande do Sul, Brazil, from 2013 to 2016

\begin{tabular}{|c|c|c|c|c|c|}
\hline \multirow{2}{*}{ Region } & \multicolumn{4}{|c|}{ Incidence $(\%)$ of cysticercosis in cattle } & \multirow{2}{*}{ Mean } \\
\hline & 2013* & 2014 & 2015 & 2016 & \\
\hline Pelotas & $0.76(113)$ & $1.24(576)$ & $1.49(518)$ & $0.76(127)$ & 1.06 \\
\hline Canguçu & $0.73(59)$ & $0.66(69)$ & $0.36(39)$ & $0.57(66)$ & 0.58 \\
\hline São Lourenço & $1.33(79)$ & $0.86(174)$ & $0.49(90)$ & 0.65 (135) & 0.83 \\
\hline Arroio Grande & $* *$ & $0.72(7)$ & $0.66(8)$ & $0.79(11)$ & 0.72 \\
\hline Capão do Leão & $0.44(1)$ & $2.75(22)$ & $1.22(13)$ & $0.85(6)$ & 1.31 \\
\hline Total & 0.82 & 1.23 & 0.84 & 0.72 & 0.90 \\
\hline
\end{tabular}

* Data as of October, 2013; ** Lack of data of 2013 from the municipality of Arroio Grande.

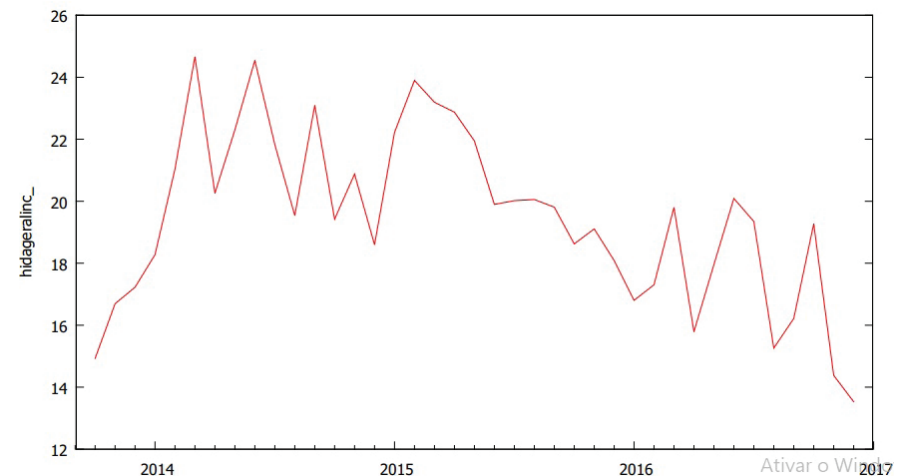

Fig.1. Time series of monthly cases of hydatidosis in cattle slaughtered in southern Rio Grande do Sul, Brazil, from 2013 to 2016.

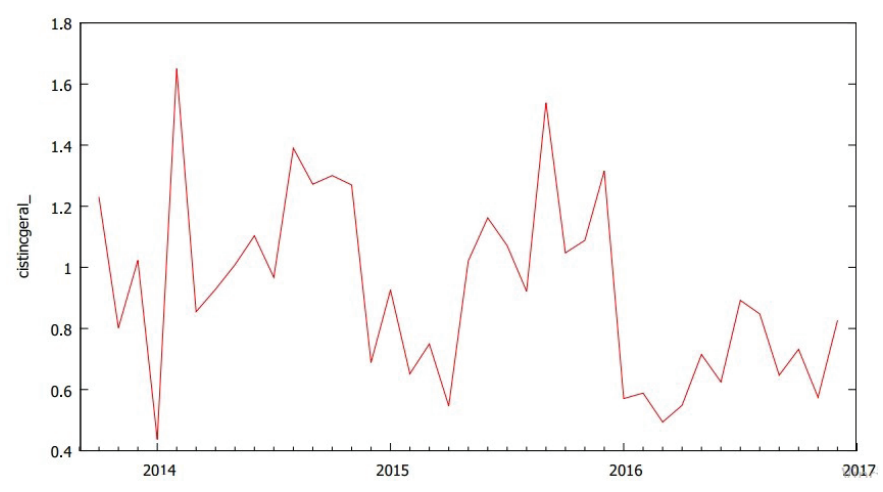

Fig.2. Time series of monthly cases of cystocercosis in cattle slaughtered in southern Rio Grande do Sul, Brazil, from 2013 to 2016. 


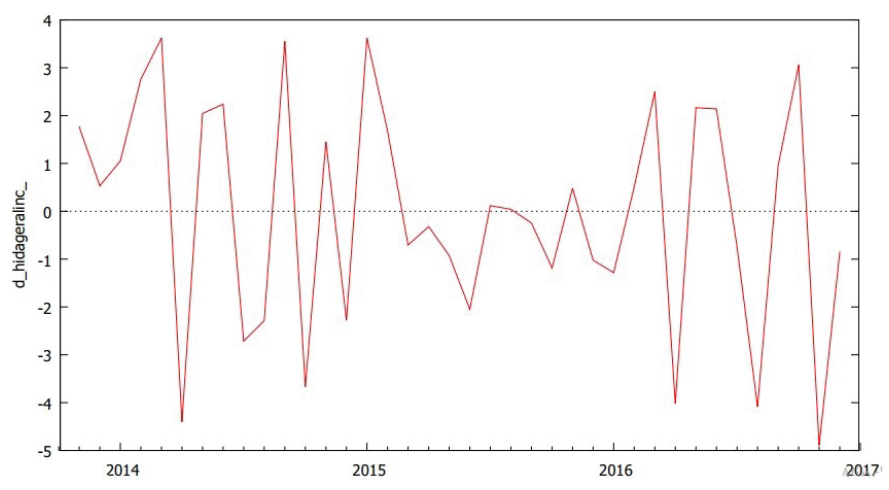

Fig.3. Assessment, without influence of the tendency component, of the cases of hydatidosis in cattle slaughtered in southern Rio Grande do Sul, Brazil, from 2013 to 2016.

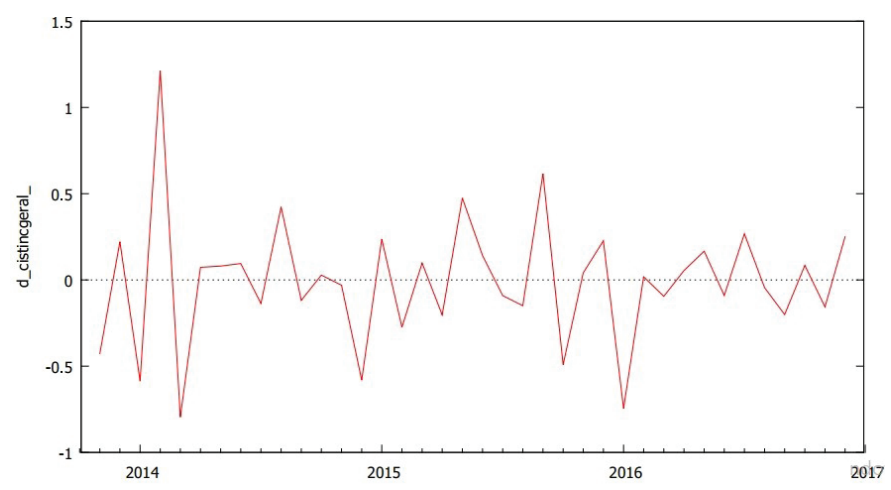

Fig.4. Assessment, without influence of the tendency component, of the cases of cystocercosis in cattle slaughtered in southern Rio Grande do Sul, Brazil, from 2013 to 2016.

\section{DISCUSSION}

Hydatidosis and cysticercosis are diseases that represent a risk to public health, and their monthly notification is mandatory (Brasil 2013). Nevertheless, no studies addressing the incidence of these diseases in cattle in Brazil have been found in the literature, which would allow evaluation of the behavior of these diseases over time in the Country.

Results of the present study show higher incidence of hydatidosis $(19.96 \%)$ compared with that of cysticercosis $(0.9 \%)$, indicating that hydatidosis is more frequent in southern Rio Grande do Sul . A study conducted by Gomes et al. (2017) also observed higher occurrence of hydatidosis than cysticercosis in the state of Rio Grande do Sul. The prevalence of hydatidosis in the state is high, especially in regions where cattle and sheep are raised jointly, because sheep are the main source of infection for dogs, which subsequently contaminate the pastures. The highest incidence of hydatidosis occurs in the southwest, southeast and south regions of the state because they concentrate the largest sheep farms, as well as because of the habit of farmers to feed their dogs with raw viscera (Santos et al. 2010, Barzoni et al. 2013, Gomes et al. 2017). The high incidence of hydatidosis found in this study is probably associated with the region evaluated.
Bovine cysticercosis occurs in all regions of Brazil, and is more frequent in the central-west, southeast and south regions of the Country (Rossi et al. 2014). The mean incidence rate of bovine cysticercosis $(0.9 \%)$ found in the municipalities of southern Rio Grande do Sul was lower than the disease occurrence $(1.09 \%)$ observed by Mazzutti et al. (2011) in a study conducted in an official inspection slaughterhouse in the same state between 2005 and 2010. The incidence of cysticercosis increases with lack of basic sanitation, resulting in contamination of water sources and the environment, increasing parasite burden and facilitating the infection of animals and humans (Santos \& Barros 2009). The low incidence of cysticercosis observed in this study may be associated with better sanitation conditions and with the smaller number of small farms in the region assessed.

Studies addressing the prevalence of bovine cysticercosis in the states of Rio de Janeiro, Paraná, Bahia, Espírito Santo, and Minas Gerais reported rates of 3.83\%, 3.97\%, 1.95\%, 1.74\%, and $4.1 \%$, respectively (Pereira et al. 2006, Souza et al. 2007, Santos et al. 2008, Cipriano et al. 2015, Garro et al. 2015), indicating that cysticercosis is an endemic disease in Brazil. Researchers believe that the prevalence of bovine cysticercosis is underestimated in Brazil, as it is mainly based on records of post-mortem inspection - a method that is often inefficient especially in the detection of mild infections (Santos et al. 2008, Bavia et al. 2012), in addition to unsupervised slaughter, in which lesions are not reported to the inspection service (Pereira et al. 2006, Santos \& Barros 2009). In the present study, it is not possible to discard the possibility that the low incidence observed is associated with failure in the detection of cysticercosis lesions and with absence of inspection in illegal slaughterhouses.

In the analysis of cases of cysticercosis without the influence of the tendency component, significant decreases in the number of cases of the disease were observed at the beginning and the end of each year, which may be associated with the vacation period of the professionals qualified to recognize lesions caused by cysticercus, leading to a decrease in the number of classified cases, which may also justify the low incidence of cysticercosis observed in this study. The presence of bovine cysticercosis results in economic losses and indicates the existence of teniasis in the human population that live close to animal farming, representing a risk to public health (Pereira et al. 2006, Santos et al. 2008). Although the occurrence of cysticercosis observed in this study was low, parasitosis is present in the region, which leads to contamination of the fields and infection of the animals.

In the time-series analysis of both diseases, a decreasing tendency and absence of seasonality were observed, indicating that there is no influence of seasonality in the occurrence of hydatidosis and cysticercosis, and that the number of cases of these diseases decreased throughout the years investigated. The decrease in the number of cases of hydatidosis and cysticercosis in the state of Rio Grande do Sul is a result of the work of raising awareness conducted in rural properties and in the municipalities of origin of affected animals (Santos et al. 2010). Despite this downward trend, hydatidosis and cysticercosis are zoonotic parasitoses that continue to occur in bovine herds in southern Rio Grande do Sul, resulting in economic losses owing to condemnation of carcasses and viscera. Furthermore, hydatidosis presents 
high incidence, with a mean of $19.96 \%$, which may be directly associated with the habit of southern region producers to use dogs to shepherd cattle, which promotes contamination of the fields and, therefore, infection of the cattle by the parasite. Sanitary surveillance and educational programs with rural producers, focusing on public policies, are fundamental for the control of these zoonoses (Barzoni et al. 2013).

\section{CONCLUSIONS}

Hydatidosis and cysticercosis are parasitic diseases affecting cattle herds in southern Rio Grande do Sul, and hydatidosis presents higher incidence compared with that of cysticercosis.

No influence of seasonality on the occurrence of hydatidosis and cysticercosis was observed, and there was a decrease in the number of cases of these diseases throughout the years evaluated (2013 to 2016).

\section{REFERENCES}

Barzoni C.S., Mattos M.J.T. \& Marques S.M.T. 2013. Prevalência de hidatidose bovina na fronteira oeste do Rio Grande do Sul, extremo sul do Brasil (1999-2007). Revista da FZVA Uruguaiana 19(1):79-87.

Bavia M.E., Carneiro D.D.M.T., Cardim L.L., Silva M.M.N. \& Martins M.S. 2012. Estatística espacial de varredura na detecção de áreas de risco para a cisticercose bovina no estado da Bahia. Arq. Bras. Med. Vet. Zootec. 64(5):1200-1208. <http://dx.doi.org/10.1590/S0102-09352012000500018>

Brasil. Ministério da Agricultura Pecuária e Abastecimento 2013. Instrução normativa no 50, de 24 de setembro de 2013. Ministério da Agricultura Pecuária e Abastecimento.

Cipriano R.C., Faria P.B., Guimarães G.C. \& Mascarenhas D.R. 2015. Prevalência de cisticercose bovina nos abatedouros com inspeção sanitária estadual no estado do Espírito Santo, Brasil. Revta Bras. Ciênc. Vet. 22(1):54-57.

Fruet A.P.B., Fabrício E.A., Kirinus J.K., Scortegagna A., Dörr A.D. \& Nörnberg J.L. 2013. Perdas econômicas oriundas das condenações de vísceras bovinas em matadouros de Santa Maria, Rio Grande do Sul. Revta Bras. Ciênc. Vet. 20(2):99-103.

Garro F.L., Santos T.M., Assis D.C.S., Heneine L.G.D., Ornellas C.B.D., Pinto P.S.A. \& Santos W.L.M. 2015. Diagnóstico do complexo teníase-cisticercose bovina em São João Evangelista, Minas Gerais, Brasil. Arq. Bras. Med. Vet. Zootec. 67(4):1063-1069. <http://dx.doi.org/10.1590/1678-4162-8196>
Gomes R.C., Feijó G.L.D. \& Chiari L. 2017. Evolução e Qualidade da Pecuária Brasileira. Nota técnica Embrapa Gado de Corte.

Kale M.C., Aral Y., Aydin E., Cevger Y., Sakarya E. \& Güloğlu S.C. 2011. Determination of by-product economic values for slaughtered cattle and sheep. Kafkas Univ. Vet. Fak. Derg. 17(4):551-556.

Mazzutti K.C., Cereser N.D. \& Cereser R.D. 2011. Ocorrência de cisticercose, fasciolose e hidatiose em bovinos abatidos sob serviço de inspeção federal no Rio Grande do Sul, Brasil, 2005 a 2010. Congresso Brasileiro de Medicina Veterinária, Florianópolis, SC, p.38. (Resumo)

Mekonnen D. \& Kebede Y. 2011. The prevalence of suicidal ideation and attempts among individuals attending na adult psychiatry out-patient clinic in Gondar, Ethiopia. Afr. Health Sci. 11(1):103-107. <PMid:21572865>

Pereira M.A.V.C., Schwanz V.S. \& Barbosa C.G. 2006. Prevalência da cisticercose em carcaças de bovinos abatidos em matadouros-frigoríficos do estado do Rio de Janeiro, submetidos ao controle do serviço de inspeção federal (SIFRJ), no período de 1997 a 2003. Arqs Inst. Biológico, São Paulo, 73(1):83-87.

Rossi G.A.M., Hoppe E.G.L., Martins A.M.C.V. \& Prata L.F. 2014. Zoonoses parasitárias veiculadas por alimentos de origem animal: revisão sobre a situação no Brasil. Arqs Inst. Biológico, São Paulo, 81(3):290-298.

Santos D.C. 2013a. Cisticercose, p.183-194. In: Rocha A. (Eds), Parasitologia. Editora Rideel, São Paulo. 448p.

Santos D.C. 2013b. Hidatidose, p.209-217. In: Rocha A. (Eds), Parasitologia. Editora Rideel, São Paulo. 448p.

Santos D.V., Santo M.C.B.E., Domingues E.H., Kohek Júnior I., Facin D.V. \& Vidor A. C. 2010. Análise das principais lesões encontradas nos abatedouros registrados na CISPOA. Informativo Técnico no 4/Ano 1.

Santos J.M.G. \& Barros M.C.R.B. 2009. Cysticercus bovis e Cysticercus cellulosae: endoparasitas de importância no comércio da carne. Revista em Agronegócios e Meio Ambiente 2(1):21-39.

Santos V.C.R., Ramos E.T.R., Almeida Filho F.S., Pinto J.M.S. \& Munhoz A.D. 2008. Prevalência da cisticercose em bovinos abatidos sob inspeção federal no município de Jequié, Bahia, Brasil. Ciênc. Anim. Bras. 9(1):132-139.

Souza V.K., Pessôa-Silva M.C., Minozzo J.C. \& Thomaz-Soccol V. 2007. Prevalência da cisticercose bovina no estado do Paraná, sul do Brasil: avaliação de 26.465 bovinos inspecionados no SIF 1710. Semina, Ciênc. Agrárias 28(4):675-684.

Tessele B., Brum S.J. \& Barros C.S.L. 2013. Lesões parasitárias encontradas em bovinos abatidos para consumo humano. Pesq. Vet. Bras. 33(7):873-889. <http://dx.doi.org/10.1590/S0100-736X2013000700008> 